\title{
Assessment of Legislature-Executive Pattern of Relations in Nigeria's Democratic Governance of the Fourth Republic: Prospects and Challenges
}

\author{
Victor Vincent Okpe* and Muhammad Fuad Othman \\ School of International Studies, College of Law, Government and International Studies, \\ Universiti Utara Malaysia, 06010 Sintok, Kedah, Malaysia
}

\begin{abstract}
This study examined legislature-executive pattern of relations in the Nigeria's democratic governance of the Fourth Republic and its implication on good governance. To realize the above aim, the study relied on descriptive qualitative method and separation of power theory. It also relied on secondary data which included journal articles, textbooks, executivelegislature documents and the 1999 Constitution of the federal republic of Nigeria. The study upon conclusion revealed that legislature-executive pattern of relations in Nigeria since the return of the Fourth Republic in 1999 had been more at loggerheads and crisisridden. It also revealed that this pattern of relations between the institutions, on several instances, had only succeeded in holding back good governance and service delivery to Nigerians. Their crises often overheated the polity, resulting into political instability, delay in the passing of bills and national budget among others. Based on the available revelations above, the study concluded that better relations, democratic consolidation and good governance can only be achieved when the executive and the legislature promote and adhere to the separation of power principles. They must maintain their constitutional jurisdiction to promote an enduring democratic practice, political stability and full representation of the people. The study will be relevant to the institutions, the public, and researchers

ARTICLE INFO

Article history:

Received: 03 April 2020

Accepted: 17 September 2020

Published: 25 December 2020

alike. Further study can also be conducted on executive-judiciary relations under the Fourth Republic.
\end{abstract}

DOI: https://doi.org/10.47836/pjssh.28.4.19

$\overline{\text { E-mail addresses: }}$

victorenugu47@gmail.com (Victor Vincent Okpe)

mfuad@uum.edu.my (Muhammad Fuad Othman)

* Corresponding author
Keywords: Democracy, executive-legislature relations, fourth republic, good governance, Nigeria 


\section{INTRODUCTION}

Globally, the drive for good governance has left many countries in a crossroad decision, especially on which best governance model to practice. However, the end of the "Cold War Era" between the United States and the Soviet Union brought a grand change in the system of governance in several countries in the world. The period, also known as the "Third Wave Era", led to the wide spread of democratization in many countries of Africa, and including Nigeria (Isma'ila, 2016). According to Isma'ila (2016), democratization is not a new phrase in the world, but was intensified at the expiration of the cold war era between the Soviet Union and the U.S. It also brought a new phase in the development of the global capitalist system characterized by the global reorganization of the movement of finance and production, and invariably promoted a spread desire for democratic governance.

In Nigeria, however, the restoration of a democratic government in late 1979 after fourteen years of military reign was quite significant in the history of Nigerian politics. The occasion led to the jettison of the Westminster Model practiced in the First Republic of 1963 (Oni, 2014). The Westminster Model was jettisoned in 1979 in favor of a Presidential democracy patterned after the U.S. even though the government did not last long as it was toppled by the military in 1984. But the 1987 political bureau, the 1989 Constitution, the Constitutional Conference of 1994, as well as the 1999 Constitution, approved the retention and practice of a presidential model as a system of governance in Nigeria, notwithstanding the bitter politics of the 1979 Second Republic (Oni, 2014). It was a momentous occasion politically for Nigerians.

Also, the return of Nigeria to a democratic government in 1999, after a long military reign, ushered in the Fourth Republic with the retention of a presidential system of government. According to Oni (2014), under the 1999 presidential democratic model, no organ of government is either more powerful or secondary to another. Every organ of the government, for example, the legislature, the judiciary or the executive, enjoys independence within its sphere of constitutional power. The legislature and the executive derive their authorities from the 1999 Constitution. For instance, the executive is headed by an executive president, while the legislature, also known as the National Assembly in Nigeria, comprises the Senate president at the upper chamber, and a Speaker at the lower chamber (Oni, 2014; Yusuf, 2018). Under this arrangement, the executive and the legislature are both separate in terms of personnel, powers and functions constitutionally.

In addition to the above and for the essence of good governance, the two political institutions (i.e. the executive and the legislature) are expected to function on a pedestal of cordial relationship. The cordial relationship is desired for good governance, service delivery, and consolidation of democracy and sustenance of a stable political system. Relying on the above perspectives, therefore the essence of this 
study is to investigate the pattern of relations between the executive and the legislature under the Nigeria's Fourth Republic democratic governance and its implication on good governance. Such assessment will reveal the institutions' pattern of relations in the Nigerian presidential democracy and the factors that drive such pattern of relations. The assessment will also help in providing a valid modality for promoting a healthy interaction between the organs for the benefit of quality service delivery and democratic consolidation. To achieve the above objective, the study is divided as thus: introduction, conceptualization of terms, constitutional roles of the institutions, materials and methods, theoretical framework, results and discussion, and finally, the conclusion.

\section{Conceptual Clarification}

In order to create an easy understanding of this study, the following concepts such as 'the legislature', 'the executive', 'democracy' and 'democratic governance', are conceptualized in the following subheadings.

The Legislature. The word 'legislature' enjoys various names across the globe (Okpe \& Taya, 2018; Oni, 2013). In Nigeria, for instance, it is described as 'the National Assembly'. In Britain, 'the Parliament', while in the U.S as 'the Congress' (Heywood, 2007; Lafenwa, 2009; Okpe \& Taya, 2018; Oni, 2013). The legislature represents a fundamental institution in the business of democratic governance (Ewuim et al., 2014;
Heywood, 2007; Obidimma \& Obidimma, 2015; Okpe \& Taya, 2018, Oni, 2013). In this same vein, Bernick and Bernick (2008), saw the legislature as a branch of the state with the essential objective of expressing and articulating the collective will of the society. It is the most significant institution of political representation (Murana \& Bakare, 2019). In Nigeria, the legislature is a state legal body established by an act of the 1999 constitution to make, change, or amend laws, and perform the duty of constituency representation in the National Assembly, as well. It also controls the government through an oversight role (Okpe \& Taya, 2018). According to Okoosi-Simbine (2010), the legislature represents a policy influencing organ. It is a lawmaking and deliberative group established to enhance a democratic political system. In fact, the legislature represents the Site of Sovereignty, First Estate of the Realm, Public Expression and the Realm of Representation of Public Will. The above submissions of OkoosiSinbine project the legislature as a legal instrument of the state and the voice of the people. These also support the description of Bernick and Bernick (2008) about the legislature. Following the above views on the legislature, hence, it can be said that the institution derives its power from the masses. It simply portrays that the existence and authority of the legislature should be exercised to represent the will of the citizens.

The Executive. In a presidential democracy such as Nigeria, the executive is seen as an irreducible organ of the state (Heywood, 
2007; Oni, 2013; Okpe \& Taya, 2018). According to Laski (1992), the executive as an organ of the state, occupies an important position in the business of the state. Furthermore, Laski noted that in many democratic nations, the executive is perceived as an agent of the state that, first, makes a decision on the final public policy choice to be sent to the legislature for an approval; and second, coordinate and articulate the various activities of departments and ministries of the state. In the same vein, Puke (2007) projected the executive as a state branch organ responsible for providing viable and good governance for the people. It is a legal state institution accountable for public policy implementation (Edosa \& Azelama, 1995). For instance, it is noted that while political edifices existed for years without an independent organ for law making, political structures that lacks the executive branch will find it challenging to succeed (Okpe \& Taya, 2018).

Furthermore, Oni (2013) and Heywood (2007) expressed that a political community could function without a constitution, assembly, judiciary or even political parties, but could not stand in the absence of the executive in charge of public policy formulation and implementation for a prosperous society. Accordingly, Anifowose and Borode (2007) believed that the executive represented a strong arm of government and basically inclined with the execution of public policies, as well as the authoritative laws of the state. The executive in Nigeria is often perceived as the main organ of the state that wills the highest power of the land in terms of governance, among other public policies, for the benefit of the people. In the above conceptualizations, therefore, the absence of the executive in a state arguably could make governance challenging.

Democracy. Democracy, arguably, has remained a consistent model of governance after the "Cold War Era" between the U.S and the Soviet Union. According to Yusuf (2018), and Okpe and Taya (2018), the concept of democracy is coined from two Greek concepts observed as 'demo' which stands for the 'populace' and 'Kratia' which means the 'rule'. They further observed that the fundamental meaning of democracy is a government owned by the people. In line with the above, Bello (2011) and Akindele and Olaopa (1997) noted that democracy, on its own, drove various ideological controversies, philosophical camps and analytical disputes. As a kind of a political system, just like any other political concept of its nature, it has been very challenging in portraying its actual meaning without ideological ambiguity (Akindele \& Olaopa, 1997; Okpe \& Taya, 2018). Operationally, it is the government of the citizens, by the citizens and for the citizens. It also tells that executive-legislature pattern of interactions can only be dissected within a political democratic space such as Nigeria. In this model of governance with respect to presidential democracy, the power, the legislature, and the executive, lie with the people who vote them into office. 
Democratic Governance. In a democratic society such as Nigeria, the essence of democratic governance cannot be undermined. Democratic governance as a phrase simply means to govern a democratic state and the people in line with the teachings and dictates of democracy. In respect to this, Isma'ila (2016) observed that democratic governance was considered genuine only when the government in her actions was noted to be transparent and accountable to the public. It can also be said effective especially when citizens' freedom of expression and association are guaranteed. Citizens must enjoy the freedom to elect and supervise those in charge of public offices, and the freedom to practice meaningful and competitive election in their country. In a democratic system as noted by Omodia and Aliu (2013), the state is anticipated to promote and support respect for citizens' rights, enhance constitutional practice, transparency and accountability. It must ensure fairness in the distribution of public resources, and respect the rule of law, both of which are the bedrocks of a democratic government. Democratic governance entails the enjoyment of the actual democratic principles in a democratic setting. In Nigeria, however, dividends of actual democracy remain questionable as the people continue to complain of poor dividends of democracy, which also has its root in the pattern of institutional relations in the country (Yusuf, 2018). Hence, building on the above overviews, the following constitutional roles of the institutions in Nigeria are considered for clearer understanding of the study.

\section{The Constitutional Roles of the Legislature in Nigeria}

In most presidential democracies like the US, Canada, Philippines, Malawi and Nigeria, the constitutional roles of the legislature are often not taken for granted. These roles primarily are to do with legislation, oversight and citizens' representation in the parliament. In Nigeria, for instance, these basic roles are captured in the 1999 constitution and they are discussed under the following subheadings.

Legislation. In several presidential democracies as mentioned above, one of the basic constitutional duties of the legislature has to do with legislation (Abonyi, 2006). As an important institution of the state (Murana \& Bakare, 2019; Okpe \& Taya, 2018), the legislature is concerned with the enhancement of state activities in which legislation happens to be one. According to Laski (1992), the legislature has the constitutional responsibility to pass state laws. It represents a constitutional organ that lays down the exceptional societal laws and rules. It enjoys the power to enact laws for the effective governance of the state. These laws by constitutional rights can come from individuals or in the form of a private member's bill, as well as from the executive (Abonyi, 2006; Benjamin, 2010). In Nigeria, to be specific, since the emergence of the Fourth Republic in 1999, legislation remains one of the cardinal roles of the legislature (Nwaubani, 2014; Oni, 2013), and this is covered under Section 4(2) of the 1999 constitution of the federal republic of Nigeria. 
Representation. Just like the legislation, representation is another constitutional responsibility of the legislature (Awotokun, 1998). It is important to note that as the present-day administration complexities have made it challenging for the people to engage directly in the business of the state as was practiced in the Greek City-States, people now participate in their government through their elected representatives (Awotokun, 1998; Baba, 2019). In this regard, therefore, the representative's ability of the legislature enables the citizens with the opportunity to offer their contribution in the governance of their state (Edosa \& Azelama, 1995). As Murana and Bakare (2019) noted, in the presentday democracies, representation remains an important requirement for the practice of democracy. In Nigeria, for instance, the lawmakers perform the responsibility of representing their constituents in the National Assembly as they defend their choices (Simmons, 2002). This role is covered in the 1999 constitution under Section 48 and 49. It has also remained in practice to date.

Oversight. An oversight role of the legislature over the activities of the executive in a presidential democracy is seen as one of the main functions of the legislature in enhancing good governance and accountability. According to Fashagba (2009), an oversight function represents a strong component activity of the legislature notwithstanding the type of government in practice. This role, as noted by Saliu and Muhammad (2010), is a necessary constitutional action of the legislature over the executive. It involves investigation and monitoring the performance of the executive. In addition to the above, the legislature enjoys the constitutional power of overseeing the government performance, as well as the capacity to hold it responsible for her actions and inactions (Fashagba, 2010). It is one of the vital roles of the parliament in Nigeria (Baba, 2019). It is also consolidated under Section 88 of the 1999 Constitution of the Fourth Republic.

Also, parts of these legislative oversight roles in Nigeria involve the approval of executive nominees and public expenditure. According to Sanyal (2009), almost all the government expenditures, except for a few as directed in the 1999 constitution, must be authorized by the legislature. He further observed that the financial oversight role, for example, is exercised as a part of the annual national budget process. The role works as a vital instrument for the sustenance and consolidation of democracy (Lafenwa \& Gberevbie, 2007). The parliament has the full legal backing to sanction expenditure of the government in the interest of the public as mentioned in Section 88 of the 1999 constitution. It is also important to note that most of these oversight roles like the approval of nominees, sanctioning of government expenditure and monitoring of its projects, are often done through committees of the National Assembly. The committees are task-oriented groups with a constitutionally defined purpose, and they function as the engine block of 
the legislature (Heywood, 2007). These committees, as further noted by Heywood (2007), apply legislative powers as they sanction executive bills and financial requests. They also scrutinize the activities of the ministries and agencies (Baba, 2019). The oversight roles of the legislature are often wide and done to promote transparency and accountability in Nigeria.

\section{The Constitutional Roles of the Executive in Nigeria}

Like the legislature in Nigeria, the executive which stands as the main engine of the government, also performs its own constitutional responsibilities. These responsibilities involve administration, legislation, and judicial functions, which are well established in Section 130(1)(2) of the 1999 constitution. They are discussed in the following subheadings and starts with the administrative role:

Administrative Role. In Nigeria, the executive organ of the government as one of the important standing instruments of good governance performs the function of administration. This role is done through controlling and coordinating the affairs of the government (Baba, 2019). As noted by Abonyi (2006), the executive coordinates and supervises the implementation of state laws made by the legislature. It equally appoints, controls, and disciplines its administrative officers. However, such appointments must be sanctioned by the legislature. The executive also controls the state military, oversees the external affairs, carries out the declaration of a state of emergency, when appropriate, and represents the country in legal treaties with other sovereign states in the international system (Anifowose, 2008). This administrative role of the executive is often cumbersome in a presidential democracy like Nigeria.

Legislative Role. Under the Nigeria's Fourth Republic 1999 constitution, legislation also falls under the constitutional roles of the executive. The executive performs this role through the initiation of public bills to the National Assembly for possible sanctioning and consideration. According to Baba (2019), the executive institution is responsible for government policies, projects and programs. It also signs bills into law and issues commands to accommodate changing occurrences in the political system. As revealed by Anifowose (2008), the executive equally performs the political function of summoning and prerogative of mercy as defined by the 1999 constitution.

Judicial Role. Part of the executive roles (aside from the administration and legislation in Nigeria) involves judicial responsibilities, such as prerogative of mercy to state offenders. This form of judicial activity for instance, may encompass reducing a judicial proclamation already passed by the judiciary on an individual. It could also involve reprieving or delaying the execution of a citizen who has committed punishable crime (Oni, 2013). According to Anifowose (2008) and Abonyi (2006), the executive has the capacity to declare an amnesty on 
citizens, such as exempting them from the legal penalty of their crimes. This kind of role, for example, was witnessed during late President Yar' Adua and the Niger Delta Militants amid 2007 to 2010 in which he pardoned their crime and offered them amnesty. It was also seen in the pardoning of some former principal officers of the National Assembly like Dr. Chuba Okadigbo, Evan Enwerem and Salisu Buhari, whom were indicted of sharp practices ranging from certificate forgery and corruption (Omotoso \& Oladeji, 2019). These roles of the executive, especially in the 1999 constitution, were quite extensive.

\section{MATERIALS AND METHODS}

This study made use of descriptive qualitative research method to explain the pattern of relations between the legislature and the executive under the Nigeria's democratic governance of the Fourth Republic and its impact on good governance. According to Wright and McKeever (2000), descriptive qualitative method fits better in the study of social phenomenon. The aim is to avail a rich description and deep thought on the phenomenon of interest (Magilvy, 2003). The above submissions by the authors, therefore, explain why the study uses the method to achieve its set objectives. Also, the study relied mainly on secondary sources of information which included literatures that discussed on institutional relations and governance such as journal articles, legislature-executive reports and books written by authorities in the field. These authorities included Joseph Fashagba,
Chiedo Nwankwor and Ola-Rotimi Mathew, Omololu Fagbadebo and Fayth Ruffin among others. Importantly, the theory of separation of power by Barron Montesquieu was also used to consolidate the study and will be discussed below.

\section{Theoretical Overview}

The Theory of Separation of Power. This study adopted the theory of separation of power because of its capacity to explain the pattern of legislature-executive relations in Nigeria. The theory was developed by Barron Montesquieu (Mbah, 2007). According to Mbah (2007), this theory stands as the bedrock of democratic ethos in both present and past centuries. De Montesquieu in 1748 published this theory also known as "the Spirit of the Laws". It was reorganized from an ancient knowledge into a more standard political theory. As noted by Sabine and Thorson (2018) for instance, Montesquieu attributed liberty in England to the separation of the judicial, executive and the legislative powers, and the balancing of such powers over each organ. It can be said that the idea of power separation in the medieval European lawmaking operated as a countermeasure against the acclaimed divine power to rule by the kings. In England to be specific, the long tussle amidst the crown, the courts of common law and the parliaments, which reached its peak in the 1688 Glorious Revolution, underscored the significance of power separation, as well as checks and balances between the institutions of the state (Mbah, 2007). 
According to Obidimma and Obidimma (2015), power separation involves the division of governmental powers and functions among the three major organs of the state which includes the executive, the legislature and the judiciary. As they further observed, this is a precedent condition for the supremacy of ruling in line with the laws of the state and with regards to a presidential democracy. Separation of power among the state organs intends to limit institutional rascality and the arbitrary use of power. It believes that a single institution of the state must not be thrusted with the entire power of the government (Mbah, 2007; Obidimma \& Obidimma, 2015). Its central proposition is to guarantee citizens' liberty and to build an effective system that promotes the rights of the people. Montesquieu strengthened his view as he observed thus:

Political liberty can only be guaranteed when abuse of power is not guaranteed. However, often experiences have proven that every man given power has the capacity to abuse or misuse such power. To avoid this, it becomes pertinent from the look of events that power must not be concentrated in one state organ. For example, when the executive, judiciary and legislative powers are surrendered under one body, then human liberty cannot be ensured. (de Montesquieu, 1748/1752, p. 173).

In the context of Nigeria for instance, the 1999 Constitution vests the powers of the state in the three major arms of the government. These arms include the executive, the legislature and the judiciary (Obidimma \& Obidimma, 2015). According to Aguda (2000), with this constitutional arrangement, no organ or level of government at any time may perform or exercise any function not assigned to her by the law, either directly or indirectly. Regrettably, the main essence of the 1999 constitution and the application of the theory in the Nigeria's Presidential democracy for good governance have not been fully achieved. This explains why since the inception of the Fourth Republic in 1999, the pattern of interaction between the legislature and the executive has often been more of a conflict of interest and crisis-ridden than cooperation and collaboration (Fatile, 2017; Godswealth et al., 2016; Momodu \& Matudi, 2013; Okon et al., 2013).

In addition to the above, the crises often occur when electing leaders of the parliament, and legislature's oversight like giving approval to executive bills, nominees and public expenditure. This was evident during the administrations of President Obasanjo (1999-2007), Goodluck Jonathan (2010-2015) and Buhari (2015-2019) (Baba, 2019). According to Oni (2013), power separation by the 1999 constitution has been guaranteed for an effective running of the state and consolidation of democratic governance, but crisis pattern of relations has often been the game. This has been the situation since 1999 as the application of the theory, as defined in the 1999 constitution, has only remained as a document but not in actual practice to promote good governance. 


\section{RESULTS AND DISCUSSION}

As mentioned in the prelude, the objective of this study was to understand legislatureexecutive pattern of relationship in Nigeria's Fourth Republic and its implication on good governance. On the above objective, however, the following results such as, conflict and collaboration pattern of interaction, leadership crisis, executive interference in parliamentary affairs, conflict over public expenditure and narrow-minded interests amongst institutions were revealed. These results are fully discussed in the following.

\section{Legislature-Executive Pattern of Relations in Nigeria}

In the present Nigerian democratic experiment under the fourth republic, the pattern of interaction between the executive and the legislature remains an issue of debate in the academic circle and among citizens. It has also been revealed to exist in two-folds, which includes conflict, and collaborative pattern of relations (Momodu \& Matudi, 2013; Osakede et al., 2017). According to Momodu and Matudi (2013), and Bassey (2002), executive-legislature relations involve the total transaction and interaction that happens between the two arms and this mostly exists in a presidential democracy such as Nigeria. The fact that the two institutions are essentially established towards achieving the objective of administering the affairs of the state in order to guarantee citizens welfare and security in Nigeria, the pattern of relations between these institutions appears complex.
In some cases, the relations are either peaceful or cordial, while in some occasions, dysfunctional and tensed (Momodu \& Matudi, 2013).

In Nigeria for example, in 2001, just two years into the Fourth Republic democratization process, leadership crisis erupted between the two institutions of the state, namely, the executive and the legislature over executive interference in the leadership selection process of the legislature. It was widely covered by the Nigerian media (Okon et al., 2013). The key implication of such crises as result had exposed, led to several impeachments of personalities in the legislature, and namely, Senate Presidents and Speakers in the House of Representatives (Okon et al., 2013; Momodu \& Matudi, 2013). Also, on several occasions, crisis relations between the two over public expenditure often heated up the system such that many feared that the Fourth Republic would collapse due to the greed and recklessness identified with the principal actors of the institutions. Due to the constant crises above, Nossiter (2010) noted that Professor Soyinka asked Nigerians to rise and rescue their country from those politicians who did not represent public interests. Also reacting to the crises, Prof. Utomi, noted in Fashagba (2010) and Aiyede (2005), observed that Nigeria could only be free from these institutional crises if the citizens would take to the streets to demand respect for the constitution and the rule of law. Allying with the scholars, Baba (2019) also revealed that ever since the emergence of the Fourth Republic, the 
interaction had been more of crisis-ridden rather than cooperation and collaboration for the interest of the people.

According to Momodu and Matudi (2013), coalition formation between the two arms only aids the narrow-minded interests of the political elites and making it elitist in both character and nature in most cases. As they explained further, this pattern of relationship did not constructively guarantee viable policy development and implementation process to benefit the public. Also, power and influence often run from the political elites at the top, and down to the citizens, via elite-inclined public policy (Anderson, 1984; Dlakwa, 2008). At this juncture, as noted by Romer and Rosenthal (1978), the legislature and the executive should uphold the constitution and develop a sound coalition that would advance service delivery to the society, as well as to promote the consolidation of democratic governance in Nigeria. They should act as state institutions of agenda setter for Nigerians rather than constant conflict at the expense of good governance and quality service delivery to the people. They should also adhere to the principles of separation of power.

\section{Challenges of Legislature-Executive Relations in Nigeria}

In Nigeria, challenges facing executivelegislature fair relations were revealed to be enormous considering their level of impacts in almost all democratic transitions in the country. With respect to the above, Igbokwe-Ibeto and Anazodo (2015) explained that many factors had posed a huge challenge to a fair relationship between the two institutions in Nigeria. These factors include dysfunctional democratic culture, corruption, executive constant interference in parliamentary affairs and personal interests of political gladiators (Momodu \& Matudi, 2013; Omotoso \& Oladeji, 2019). Expanding the factors further, Rockman (1983) revealed oversight role, executive dominance and ignorance of the provisions of the 1999 constitution by the institutions.

As Omotoso and Oladeji (2019) further observed, democracy in Nigeria is still far away from being consolidated due to the evidence of the military hangover which has persisted in the system. Democratic principles like institutional accountability, free and fair elections and the rule of law are still a rarity in the system. Also, close to the above is the deep-rooted culture of corruption amongst the political institutions, which is a consequence of military misrule for several years in Nigeria. The 1999 constitution empowers the legislature to perform oversight roles such as screening executive nominees, approval of expenditure and even to impeach the president, but however it is disheartening because the executive continues to interfere in the exercise of such functions. Additionally, several members of the institutions also pursue their personal interests which are usually at variance with their basic functions. These issues create challenges to the institutions' fair relations (Momodu \& Matudi, 2013; Omotoso \& Oladeji, 2019). 
In addition to the above as IgbokweIbeto and Anazodo (2015) further noted, the 1999 constitution provided that making of laws should be the responsibility of the legislature for better governance in the country, while the executive should maintain the constitutional role of policy implementation. However, it has remained doubtful and debatable if the two institutions understand and have achieved the basic intents and meanings as enrolled in the constitutional provisions of their roles. This is left to logic that the struggle for achieving good governance and democratic consolidation in the country has continued to exist as a mirage, and most particularly in the obvious high rate of clashes among the organs. These clashes by implication succeed in giving birth to enormous poverty, persistent corruption among politicians and other ills among public office holders in the government (Igbokwe-Ibeto \& Anazodo, 2015). Following the above without alteration, therefore, one can say that there exists a misplacement of priority among the two institutions and such misplacement would continue to remain as a challenge between the institutions if the situation is not given a timely arrest.

\section{The State of Democratic Governance in Nigeria}

In Nigeria, the return of democratic governance in 1999 which marks the beginning of the Fourth Republic was a welcome development among many Nigerians. According to Yusuf (2018), the return of democratic governance in the country after a long time of military interference in the nation's politics came with a lot of positive expectations. These expectations, however, have not been met as democratic consolidation and good governance have continued to remain a mirage through the activities of the institutions of the government like the executive and the legislature. In view of the above, Osakede et al. (2017) opined that democratic governance encompassed the sustainability of a country. As he explained further, this sustainability had to do with the enduring ability to maintain the independence of government institutions like the legislature, and the executive through the principle of separation of power, the exercise of authority in line with the constitutional provisions, respect for the fundamental rights and freedoms of citizens, the practice of accountability and transparency in the system. According to Bassey (2002), a country which is known with the practice of democratic governance is one that practices and promotes a wide degree of political participation, acceptance of a diverse system of political parties, tolerance of the media, as well as a vibrant civil society. It is also one that ensures faster development through a fair political process, viable institutions and regulations to enhance human capacity and faster economic growth. In Nigeria, however, these indices for good democratic governance have remained a tall dream (Isma'ila, 2016; Yusuf, 2018). 


\section{Implication of Legislature-Executive Tense Pattern of Relationship on Good Governance in Nigeria}

Generally, the pattern of relationship between the legislature and the executive by implication can produce either positive or negative impact on good governance. In view of the above, Momodu and Matudi (2013) in their study explained that in an atmosphere of friendly relations between the legislature and the executive, interaction would be more positive, democracy consolidated, and good governance promoted. It would also enhance parliamentary oversight, strengthen policies for the public and promote responsible leadership. Friendly relations in addition, would equally promote institutional accountability, transparency and aid the legislature to develop important policies for the system, and finally, promote an effective representation and participation of the people in the affairs of the state. All these are the hallmarks of a democratic government.

In contrast to the above, however, Osakede et al. (2017) revealed that the constant face-off between the executive and the legislature had continued to generate ineffective policy development and implementation in Nigeria. According to Ukase (2003), this pattern of tense relationship between the institutions hugely affects the democratic processes and often time, overheat the national polity. The two institutions are always in struggle for supremacy and control over public policy making and implementation, and thereby suffer the ethos and the principles of power separation enshrined in the country's 1999 constitution (Momodu \& Matudi, 2013). This tensed pattern of relation between the institutions undermines the pace for effective governance. It promotes hostility, suspicion, political instability, culture of impunity and abuse of the rule of law (Fatile \& Adejuwon, 2016). The skirmishes never consolidate good governance and stable political system. In this respect therefore, it is important to note that the viability of any presidential democracy lies in the provision of actual dividends of good governance to the people, which can be achieved via healthy interaction among the state organs (Nwokeoma, 2011, as cited in Fatile, 2017).

Following from the above revelations as presented by Momodu and Matudi (2013); and Osakede et al. (2017), it is important to note that in an atmosphere of crisis-ridden relationship between the two institutions, the implication of such tensed pattern of relationship would always impact more negatively on the political system. It would affect sound policy development and implementation, as well as endangers the healthy running of the state affairs. For example, the passing of the 2016 and 2017 national budgets into law had witnessed a serious delay and disagreement between the two chambers. On this issue, Ayuali (2003) noted that as a result of the unfriendly relations between the executive and the legislature in Nigeria, the economy had continued to face serious confrontations and various challenges such as democratic instabilities that had featured the country for decades now. 


\section{Managing Legislature-Executive Relations in Nigeria}

In Nigeria, several factors have been identified to be responsible for the challenges of a healthy legislature-executive interaction for good governance. As seen above, the factors include executive interference in parliamentary affairs, oversight role, corruption amongst others (Baba, 2019). However, the challenges can be managed in order to achieve a healthy interaction between the institutions. The healthy interaction is important as it would lead to a healthy security, speedy passage of bills and national budget, peace and good governance. The institutions must also develop a synergy to promote viable policy making and implementation process to drive good governance and consolidate democracy.

According to Remington (2004), for the institutions to be able to perform their constitutional roles, it is important that some degree of cooperation and understanding exist between them. Accordingly, Omotoso and Oladeji (2019) also noted the need to practice and adhere to the primary views of the principle of separation of power as established in the Nigerian 1999 constitution. In addition, the legislature must be given the free hand to perform its functions, while the executive must comply with the legislature in performing their roles. Collaboration and harmonious interaction between the legislature and the executive remain pertinent for achieving national development, good governance and democratic consolidation (Shehu, 1999). Better relations unarguably remain the key in achieving anything related to good governance in Nigeria, which without it, good governance will only remain a mirage.

\section{CONCLUSION}

In a presidential democracy, legislatureexecutive healthy interaction cannot be overemphasized. They play vital roles in aiding a viable political system, delivery of good governance and democratic consolidation. With respect to the above, this study was centered on the objective to understand legislature-executive pattern of relations in Nigeria and its implication on good governance. To realize the above objective, the study relied on descriptive qualitative research method and secondary information. The results that emerged disclosed that since the return of democratic rule in 1999 in Nigeria, executive-legislature relations had been more of a crisis rather than cooperation. It also revealed that this institutional crisis between the two institutions often led to delays in the passing of national budgets, and bills, amongst other important policies in the country. The crisis equally derails the delivery of good governance, promote political instability and denial of democratic consolidation in the country. At this juncture, it can be concluded that the pattern of relations between the institutions impact more negatively on good governance, and therefore, synergy becomes necessary to promote good governance. Finally, the study would however, benefit the institutions, the public, and researchers alike. Further study can be conducted on executive-judiciary relations under the Nigeria’s Fourth Republic. 


\section{ACKNOWLEDGEMENT}

The authors sincerely acknowledge the support by the School of International Studies, Universiti Utara Malaysia. Most importantly, thousands thanks to Associate Professor Muhammad Fuad Othman, the Dean for the School of International Studies, who also equals as my supervisor.

\section{REFERENCES}

Abonyi, N. N. (2006). Intergovernmental relations in democratic federations. Enugu, Nigeria: John Jacob's Classic Publishers.

Aguda, O. O. (2000). Understanding the Nigerian constitution of 1999. Lagos, Nigeria: MIJ Professional Publishers Ltd.

Aiyede, R. E (2005). Executive-legislature relations in Nigeria's emerging presidential democracy. University of Lagos Journal of Politics, 2(1), 65-87.

Akindele, S. T., \& Olaopa, O. R. (1997). Local government as agent of grassroots democracy in Nigeria; A theoretical and empirical analysis. The Nigerian Journal of Political Behavior, 1(1), 71-81.

Anderson, J. (1984), Public policy making. New York, USA: Holt Reinhart and Winston.

Anifowose, A. Y., \& Borode, A. M. (2007). A photo geological study of the fold structure in okemesi area, Nigeria. Journal of Mining and Geology, 43(2), 125-130. doi: 10.4314/jmg. v43i2.18872

Anifowose, R. (2008). The structure and organization of government. In R. Anifowose \& F. Enumuo (Eds.), Elements of Politics (pp. 171-190). Lagos, Nigeria: Sam Ironsi Publication.

Awotokun, A. M. (1998). Legislative, executive and judicial duties in sustaining democracy: A theoretical discourse in Nigeria. Indian SocioLegal Journal, 24(1), 53-60.
Ayuali. (2003). Democratic consolidation: Is impeachment the panacea? In Osakede et al. (Eds.), Executive-legislative face-off in Nigerian democracy and its implication on good governance (pp. 60-68). Benue State University, Nigeria.

Baba, Y. T. (2019). Executive-legislature relations: Evidence from Nigeria's Fourth Republic. In J. Y. Fashagba, O. M. Ajayi, \& C. Nwankwo (Eds.), The Nigerian National Assembly (pp. 143-164). Gewerbestrasse, Switzerland: Springer, Cham.

Bassey, A. (2002). Issues in legislative affairs: A study of Cross River State House of Assembly. Ibadan, Nigeria: The Institute of Social Science and Administration (TISSA), 1,2,3.

Bello, K. (2011). Resurgence of democracy and its impact on good governance in Africa. Research World Journal of Arts, Science and Commerce, 2(2), 51-58.

Benjamin, S. A. (2010). National assembly: The limit of party politics in legislative process. Nigeria Journal of Legislative Affairs, 3(1\&2), 44-72.

Bernick, E. M., \& Bernick, L. E. (2008). Executivelegislative relations: Where you sit really does matter. Social Science Quarterly, 89(4), 969-986. https://doi.org/10.1111/j.15406237.2008.00594.x

de Montesquieu, B. (1752). The spirit of law (T. Nurgent, Trans.). Ontario, Canada: Batoche Books. (Original work published 1748).

Dlakwa, H. (2008). Concepts and models in public policy formulation and analysis. Maiduguri, Nigeria: Pyla-mark Services Ltd.

Edosa, E., \& Azelama, J. (1995). Institutions of government. In A. O. IIkelegbe (Ed.), Politics and government: An introductory and comparative Perspective (pp. 35-55). Benin City, Nigeria: Uri publishing Ltd.

Ewuim, N. C., Nnamani, D. O., \& Eberinwa, O. M. (2014). Legislative oversight and good 
governance in Nigeria National Assembly: An analysis of Obasanjo and Jonathan's administration. Review of Public Administration and Management, 3(6), 140-153.

Fashagba, J. Y. (2009). Legislative oversight under the Nigerian presidential system. The Journal of Legislative Studies, 15(4), 439-459. https://doi. org/10.1080/13572330903302497

Fashagba, J. Y. (2010). Deconstitutionalizing? Democratic governance in Nigeria: Assessing executive-legislative handling of executivepower vacuum in the fourth republic. Journal of Ideas on Africa and the African Diaspora, 4(1), 7-42.

Fatile, J. (2017). Legislative-executive relations and public policy formulation and implementation in Lagos State, Nigeria. OIDA International Journal of Sustainable Development, 10(06), 41-52.

Fatile, J. O., \& Adejuwon, K. O. (2016). Legislativeexecutive conflicts and democratic governance in Nigeria's fourth republic. International Journal of Innovation Research in Social Science and Management Techniques, 3(1), 91-110.

Godswealth, I. C., Ahmad, Z. B., \& Jawan, J. (2016). Factors influencing the executive and legislative conflict in Nigeria political development. IOSR Journal of Humanities and Social Science, 21(8), 20-25.

Heywood, A. (2007). Politics (3rd ed.). New York, USA: Palgrave Macmillan's.

Igbokwe-Ibeto, C. J., \& Anazodo. R. O. (2015). Managing executive-legislature relationship for good governance and service delivery in Nigeria. Review of Public Administration and Management,4(8),13-24.

Isma'ila, Y. (2016). Malpractices in Nigeria's Fourth Republic elections: Challenges of democratic governance (Doctoral dissertation), Universiti Utara Malaysia, Malaysia.
Lafenwa, S. A. (2009, December). The legislature and the challenges of democratic governance in Africa: The Nigerian case. Paper presented at a Conference on Governance and Development on Democratization in Africa: Retrospective and Future Prospects. University of Leeds, England.

Lafenwa, S., \& Gberevbie, D. E. I. (2007). Legislative oversight and cost of governance in Nigeria. In A. S. Akpotor (Ed.), Cost of governance in Nigeria: An evaluative analysis. (pp. 216-244). Ekpoma, Nigeria: Ambrose Ali University Publishing House.

Laski, H. J. (1992). A grammar of politics. London, England: George Allen and Unwin.

Magilvy, J. K. (2003). Qualitative designs. In K. S. Oman, M. Krugman, \& R. Fink (Eds.), Nursing research secrets (pp. 123-128). Philadelphia, USA: Hanley \& Belfus, Inc.

Mbah, P. (2007). Executive-legislative relations in Nigeria: The presidency and the national assembly, 1999-2006. Nigerian Journal of Social Sciences, 4(1), 187-210.

Momodu, A. J., \& Matudi, D. (2013). The implications of executive-legislative conflicts on good governance in Nigeria. Public Policy and Administration Research, 3(8), 30-42.

Murana, A. O., \& Bakare, A. R. (2019). Constituencylegislature relations in Nigeria. In J. Y. Fashagba, O. R. Ajayi, and C. Nwankwo, (Eds.), The Nigerian National Assembly (pp. 73-89). Gewerbestrasse, Switzerland: Springer, Cham.

Nossiter, A. (2010, January 12). Protest in Nigeria over absent leader. The New York Times. Retrieved March 15, 2020, from https://www.nytimes. com/2010/01/13/world/africa/13nigeria.html

Nwaubani, O. O. (2014). The legislature and democracy in Nigeria (1960-2003): History, constitutional role and prospects. Research on Humanities and Social Sciences, 4(15), 81-90. 
Obidimma, A. E., \& Obidimma, E. O. C. (2015). The legislative-executive relations in Nigeria's presidential democracy. International Journal of Business \& Law research 3(1), 71-80.

Okon, B. A., Abia, R. P., Ekok, O. C., \& Antigha, B. U. (2013). An examination of causes and consequences of conflict between legislature and executive in Cross River State, Nigeria. Academic Journal of Interdisciplinary Studies, 2(1), 179-187. doi: 10.5901/ajis/2013.v2n1p179

Okoosi-Simbine, A. T. (2010). Understanding the role and challenges of the legislature in the fourth republic: The case of Oyo State House of Assembly. Nigeria Journal of Legislative Affairs, 3(1-3), 1-27.

Okpe, V. V., \& Taya, S. (2018). Institutional perspective: Legislative-executive relations under Nigeria's democratic dispensation. International Journal of Research, 5(22), 828851.

Omodia, S. M. \& Aliu, M. (2013). Governance and threats to national security in emerging democracies: A focus on the Nigerian fourth republic. Research on Humanities and Social Sciences, 3(4), 36-42.

Omotoso, F., \& Oladeji, O. (2019). Legislative oversight in the Nigerian Fourth Republic. In J. Y. Fashagba, O. R. Ajayi, and C. Nwankwo, (Eds.), The Nigerian National Assembly (pp. 57-72). Gewerbestrasse, Switzerland: Springer, Cham.

Oni, E. O. (2014). The challenges of democratic consolidation in Nigeria, 19992007. International Journal of Politics and Governance, 5(5.1), 1-29.

Oni, S. O. (2013). Legislature-executive relations in the presidential system: A study of Lagos and Ogun States, Nigeria, 1999-2011 (Doctoral dissertation), Covenant University, Nigeria.
Osakede, K. O., Ijimakinwa, S. O., Adesanya, T. O., \& Oshineye, A. A. (2017). Executivelegislative face-off in Nigerian democracy and its implication on good governance. Review of Public Administration and Management, 6(12), 60-68. doi: 10.12816/0043961

Puke, T. A. (2007). Substance of government. Lokoja, Nigeria: JHL Printing and Publications.

Remington, T. (2004). Separation of powers and legislative oversight in Russia: Legislature and Oversight. In R. Pelizzo and R. Stapenhurst (Eds.), WBI Working Paper Series: Series on Contemporary Issues in Parliamentary Development (pp. 9-16). Washington, USA: The World Bank.

Rockman, B. (1983). Legislative-executive relations. In L. Gerhard, P. Samuel, and Romer (Eds.), Parliamentary and legislature series (pp. 1-199). Ohio, USA: Ohio University.

Romer, T., \& Rosenthal, H. (1978). Political resource allocation, controlled agendas, and the status quo: Public choice. In S. Martin, T. Saalfeld, and K. W. Strom, (Eds.), Handbook of legislative research (pp. 27-43). Cambridge, England: Harvard University Press.

Sabine, G. H., \& Thorson, T. L. (2018). A history of political theory (4th ed.). New Delhi, India: Oxford and IBH Publishing Co. PVT Ltd.

Saliu, H., \& Muhammad, A. A. (2010). Exploring the parliament. Nigeria Journal of Legislative Affairs, 3(1-2), 73-89.

Sanyal, K. (2009). The executive versus the legislature. New Delhi, India: PRS Legislative Research.

Shehu, A. Y. (1999). The impact of governance on macroeconomic management. In Governance and the Nigerian Economy: Proceedings of the One-day Seminar, January 19 (pp. 9-25). Ibadan, Nigeria. 
Simmons, C. W. (2002). Legislative oversight of the executive branch. California, USA: California Research Bureau.

Ukase, P. I. (2003). Issues, dimension and perspective on the executive conflict in Nigeria: The Benue State experience, 1992-2003 (Master's thesis), Benue State University, Nigeria.
Wright, J. G., \& McKeever, P. (2000). Qualitative research: Its role in clinical research. Annals of the Royal College of Physicians and Surgeons of Canada, 33, 275-280.

Yusuf, A. Y. (2018). The legislative functions and democratic consolidation in Nigeria 's Fourth Republic, 1999-2015 (Doctoral dissertation), Universiti Utara Malaysia, Malaysia. 